\title{
Implementasi Evaluasi Kinerja Guru Di MA Al-Islam Joresan Mlarak Ponorogo
}

\author{
Harjali \\ STAIN Ponorogo \\ Email: luc_ky_09@yahoo.co.id
}

\begin{abstract}
The success of education is determined by the readiness of teachers in preparing their students through learning activities. The goal of this research is to know the implementation of the performance evaluation of teachers in MA Al-Islam Joresan Mlarak Ponorogo. Qualitative method is used to describe the implementation of teacher performance evaluation program. The result shows that the teacher performance evaluation program is needed by teachers to improve their performance so that quality standards can be reached. The program evaluation of MA Al-Islam Joresan Mlarak Ponorogo refers to the principle of management that includes four components, namely (1) Performance evaluation planning, (2) Organizing the performance evaluation, (3) implementing the performance evaluation, (4) Monitoring the performance evaluation of teachers in MA Al-Islam Joresan Mlarak Ponorogo.
\end{abstract}

\begin{abstract}
Abstrak
Keberhasilan penyelenggaraan pendidikan sangat ditentukan oleh kesiapan guru dalam mempersiapkan peserta didiknya melalui kegiatan belajar mengajar. Tujuan penelitian ini bertujuan untuk mengetahui penyelenggaraan evaluasi kinerja guru di MA Al-Islam Joresan Mlarak Ponorogo. Metode penelitian kualitatif digunakan untuk mendeskripsikan mengenai pelaksanaan program evaluasi kinerja guru. Hasil penelitian menunjukkan bahwa agar kinerja guru dapat selalu ditingkatkan dan mencapai standar tertentu, maka dibutuhkan suatu manajemen kinerja. Begitu pula dengan program evaluasi kinerja guru di MA. Al-Islam Joresan Mlarak Ponorogo, program tersebut juga mengacu pada prinsip manajemen yang meliputi empat komponen, yaitu (1) Perencanaan evaluasi kinerja, (2) Pengorganisasian evaluasi kinerja, (3) Pelaksanaan evaluasi kinerja, (4) Pengawasan evaluasi kinerja guru di MA Al-Islam Joresan Mlarak Ponorogo.
\end{abstract}

Kata Kunci: Evaluasi, Kinerja Guru 


\section{$80 \mid$ Harjali}

\section{A. Pendahuluan}

Peningkatan mutu pendidikan ditentukan oleh kesiapan sumber daya manusia yang terlibat dalam proses pendidikan. Guru merupakan salah satu faktor penentu tinggi rendahnya mutu hasil pendidikan yang mempunyai posisi strategis sehingga setiap usaha peningkatan mutu pendidikan perlu memberikan perhatian besar kepada peningkatan guru baik dalam segi jumlah maupun mutunya.

Guru merupakan unsur yang sangat mempengaruhi tercapainya tujuan pendidikan di sekolah selain unsur murid dan fasilitas lainnya. Kehadiran guru dalam proses pembelajaran di sekolah masih tetap memegang peranan yang penting. Guru merupakan faktor yang sangat dominan dan paling penting dalam pendidikan formal pada umumnya karena bagi siswa guru sering dijadikan tokoh teladan bahkan menjadi tokoh identifikasi diri. ${ }^{1}$ Keberhasilan penyelenggaraan pendidikan sangat ditentukan kesiapan guru dalam mempersiapkan peserta didiknya melalui kegiatan belajar mengajar. Namun demikian posisi strategis guru untuk meningkatkan mutu hasil pendidikan sangat dipengaruhi oleh kemampuan profesional guru dan mutu kinerjanya.

Guru dituntut memiliki kinerja yang mampu memberikan dan merealisasikan harapan dan keinginan semua pihak terutama masyarakat umum yang telah mempercayai sekolah dan guru dalam membina anak didik. Dalam meraih mutu

\footnotetext{
${ }^{1}$ Wijaya, C. dan Rusyan A.T, Kemampuan Dasar Guru dalam Proses
} Belajar Mengajar (Bandung: PT. Remaja Rosdakarya, 1994), hlm. 143. 


\section{1 | Harjali}

pendidikan yang baik sangat dipengaruhi oleh kinerja guru dalam melaksanakan tugasnya sehingga kinerja guru menjadi tuntutan penting untuk mencapai keberhasilan pendidikan. Secara umum mutu pendidikan yang baik menjadi tolok ukur bagi keberhasilan kinerja yang ditunjukkan guru. Kenyataan ini mengharuskan guru untuk selalu meningkatkan kemampuannya terutama memberikan keteladanan, membangun kemauan, dan mengembangkan kreativitas peserta didik dalam proses pembelajaran.

Upaya untuk peningkatan kemampuan guru secara individual telah banyak dilakukan oleh guru yang bersangkutan dengan cara melanjutkan belajar ke jenjang pendidikan yang lebih tinggi seperti S-2 dan S-3. Pemerintah juga telah berusaha meningkatkan kemampuan dan kelayakan guru, dimulai dari pendidikan pra jabatan atau yang biasa disebut pre-service training hingga pendidikan setelah meniti jabatan guru atau inservice training seperti penataran, seminar, loka karya, pelatihan dan studi lanjut di lembaga pendidikan formal. Bahkan saat ini pemerintah mewajibkan seorang guru harus memiliki kualifikasi akademik, kompetensi, sertifikat pendidik, sehat jasmani dan rohani serta harus memiliki kemampuan untuk mewujudkan tujuan pendidikan nasional. Kualifikasi akademik diperoleh melalui pendidikan tinggi program sarjana atau diploma empat.

Berdasarkan latar belakang tersebut peneliti hendak melihat bagaimana program evaluasi kinerja guru di MA Al-Islam Joresan Mlarak Ponorogo. Pilihan peneliti terhadap lembaga 


\section{2 | Harjali}

pendidikan ini didasarkan pada suatu fenomena bahwa MA AlIslam Joresan Mlarak Ponorogo adalah salah satu sekolah yang mengalami perkembangan yang cukup bagus, baik dari segi peningkatan kuantitas siswa maupun dari kualitas prestasi gurunya. Setelah peneliti melakukan penelitian pendahuluan dan menanyakan beberapa pertanyaan kepada kepala sekolah. Dari informasi tersebut MA Al-Islam Joresan Mlarak memiliki prestasi yang cukup besar baik dalam kancah lokal mupun nasional. Selain itu lembaga pendidikan ini memiliki tenaga pengajar yang profesional dalam berbagai bidang. Hal ini bisa dilihat dari keberhasilannya dalam mendidik siswa-siswinya. Hal lain yang membuat peneliti tertarik untuk mengambil lokasi penelitian di MA Al-Islam JoresanMlarak dikarenakan lembaga ini telah melakukan penerapan konsep multiple intelegences dalam proses belajar mengajar. Dengan demikian, peserta didik akan mendapat pelayanan pendidikan sesuai dengan jenis kecerdasannya.

Berdasarkan uraian di atas, fokus utama penelitian ini adalah bagaimanakah penyelenggaraan evaluasi kinerja guru di MA Al-Islam Joresan Mlarak Ponorogo? Penelitian dimaksudkan untuk mendeskripsikan secara komprehensif tentang implementasi evaluasi kinerja guru di MA Al-Islam Joresan Mlarak Ponorogo, mencakup kegiatan perencanaan evaluasi kinerja, pengorganisasian evaluasi kinerja, pelaksanaan evaluasi kinerja dan pengawasan pelaksanaan evaluasi kinerja guru diMA Al-Islam Joresan Mlarak Ponorogo. 


\section{3 | Harjali}

\section{B. Kajian Teori}

Istilah kinerja merupakan terjemahan dari bahasa Inggris "performence" yang diartikan prestasi kerja, pelaksanaan kerja, hasil kerja dan penampilan kerja. ${ }^{2}$ Sedangkan menurut Snell yang dimaksud dengan kinerja adalah merupakan kulminasi dari tiga elemen yang saling berkaitan, yaitu keterampilan, upaya dan sifat eksternal. Tingkat keterampilan merupakan bahan mentah yang dibawa seseorang ke tempat di mana ia bekerja. Seperti pengetahuan, kemampuan, kecakapan interpersonal serta kecakapan-kecakapan teknis. Tingkat upaya digambarkan sebagai motivasi yang diperlihatkan oleh seseorang untuk menyelesaikan pekerjaannya. Sedangkan sifat eksternal adalah tingkat sejauh mana kondisi eksternal dapat mendukung kinerja seseorang. ${ }^{3}$

Dari beberapa penjelasan tentang pengertian kinerja di atas dapat disimpulkan bahwa kinerja guru adalah kemampuan yang ditunjukkan oleh guru dalam melaksanakan tugas atau pekerjaannya. Kinerja dikatakan baik dan memuaskan apabila tujuan yang dicapai sesuai dengan standar yang telah ditetapkan.

Di dalam Undang-Undang Guru dan Dosen Bab VI tentang Standar Pendidik dan Tenaga Kependidikan, pasal 28 dijelaskan bahwa seorang guru harus memiliki sedikitnya empat kompetensi dasar yaitu kompetensi pedagogik, kompetensi

${ }^{2}$ Mitchell, People In Organizational Understanding The Behavior, tejemah Sedarmayanti, (McGraw-Hill: Kogakhusa, 1978),

${ }^{3}$ Wexley dan Yukl, Perilaku Organisasi dan Psikologi Personalia (Jakarta: PT. Bina Aksara: 1992), hlm. 112. 
kepribadian, kompetensi profesional dan kompetensi sosial yang diperoleh melalui pendidikan profesi. ${ }^{4}$

Secara singkat keempat kompetensi tersebut dapat dijelaskan sebagai berikut: Kompetensi pedagogik adalah kemampuan mengolah pembelajaran peserta didik yang meliputi pemahaman terhadap peserta didik, perancangan dan pelaksanaan pembelajaran, evaluasi hasil belajar, dan pengembangan peserta didik untuk mengaktualisasikan berbagai potensi yang dimilikinya. Kompetensi kepribadian adalah kemampuan kepribadian yang mantap, stabil, dewasa, arif, dan berwibawa, menjadi teladan bagi peserta didik, dan berakhlak mulia. Kompetensi profesional adalah kemampuan penguasaan materi pembelajaran secara luas dan mendalam yang memungkinkannya membimbing peserta didik memenuhi standar kompetensi yang ditetapkan dalam Standar Nasional Pendidikan. Kompetensi sosial adalah kemampuan pendidik sebagai bagian dari masyarakat untuk berkomunikasi dan bergaul secara efektif dengan peserta didik, sesama pendidik, tenaga kependidikan, orang tua/wali peserta didik, dan masyarakat sekitar.

Kinerja merupakan suatu hasil kerja yang diperoleh seseorang baik secara kuantitatif maupun kualitatif melalui kegiatan-kegiatan atau pengalaman-pengalaman dalam jangka waktu tertentu. Kinerja guru juga merupakan kemampuan yang dihasilkan oleh guru dalam melaksanakan tugas, kewajiban dan

\footnotetext{
${ }^{4}$ Undang-undang Guru dan Dosen (Jakarta: Cemerlang, 2005), hlm. 153.
} 


\section{5 | Harjali}

tanggung jawabnya yaitu mendidik, mengembangkan ilmu pengetahuan, menjadi orang tua kedua dari anak didik, mencerdaskan dan menciptakan anak didik yang berkualitas.

\section{Evaluasi Kinerja Guru}

Secara spesifik pengertian evaluasi kinerja menurut Hadari Nawawi dalam Frank Jefkins, Public Relations, merupakan penilaian secara sistematik tentang relevansi antara tugas-tugas yang diberikan dengan pelaksanaannya oleh seorang pegawai dengan cara mengidentifikasi, mengukur dan mengelola pekerjaan yang dilaksanakan oleh para pekerja di lingkungan suatu organisasi. Kegiatan pengukuran tersebut merupakan usaha untuk menetapkan keputusan tentang sukses atau tidaknya pelaksanaan pekerjaan yang dilakukan oleh karyawan. ${ }^{5}$

Evaluasi kinerja dalam hal ini disebut juga dengan penilaian kinerja. Penilaian dilakukan secara sitematis terhadap kinerja karyawan dan potensi mereka untuk berkembang. Penilaian kinerja mencakup prestasi kerja, cara bekerja, dan pribadi mereka. Sedangkan penilaian terhadap potensi untuk berkembang mencakup kreativitas dan hasil belajar atau kemampuan mengembangkan profesinya. ${ }^{6}$

Yang dimaksud dengan prestasi kerja ialah hasil pekerjaan, apakah pekerjaan tersebut sudah sesuai dengan kritetia yang telah ditentukan sebelumnya dan apakah sudah tepat

\footnotetext{
${ }^{5}$ Frank Jefkins, Public Relations, (Jakarta: PT Rajawali Press, 1992), hlm.157.

${ }^{6}$ Made Pidarta, Manajemen Pendidikan Indonesia, (Jakarta: Rineka Cipta, 2004), Cet.ke-2, hlm. 135.
} 


\section{6 | Harjali}

penyelesaiannya dengan alokasi waktu yang telah diberikan. Apakah hasil pekerjaan itu sudah memenuhi akuntabilitas atau sekedar selesai. Cara bekerja mencakup ciri-ciri efektivitas dan efifiensi dalam bekerja. Sedangkan ukuran penilaian pribadi karyawan ialah butir-butir pancasila yang telah diuraikan antara lain sudah termasuk di dalamnya dedikasi dan motifasi yang tinggi untuk berjuang dalam dunia pendidikan.

Kreativitas seorang karyawan atau guru dapat dilihat dari aktifitas orang tersebut dalam melaksanakan tugas sehari-hari. Orang yang kreatif sering berinisiatif melakukan sesuatu yang belum pernah ada di lingkungan kerjanya dan bahkan sering mengemukakan ide-ide yang baru. Kalau seseorang sedang belajar, juga akan tampak pada hasil karyanya yang tidak monoton, suatu hasil karya yang menunjukkan buah pikiran baru dan berguna bagi pengembangan dan proses pendidikan.

Manajemen evaluasi kinerja guru meliputi empat fungsi manajemen yaitu: perencanaan evaluasi kinerja, pengorganisasian evaluasi kinerja, pelaksanaan program evaluasi kinerja, serta evaluasi evaluasi kinerja itu sendiri.

\section{Perencanaan Evaluasi Kinerja Guru}

Perencanaan sebagian besar adalah sebuah aktivitas kognitif yang menyangkut pemrosesan informasi, menganalisis, dan memutuskan. ${ }^{7}$ Dalam istilah organisasi terdapat beberapa jenis perencenaan yaitu: perencanaan strategik termasuk

7 Gary Yukl. Alih bahasa: Jusuf Udaya, Kepemimpinan Dalam Organisasi, Jakarat: Prenhalindo, 1994), hlm. 66. 


\section{7 | Harjali}

penentu sasaran-sasaran strategik, strategi-strategi kinerja, dan kebijakan-kebijakan yang luas bagi unit organisasi. perencanaan operasional adalah pengaturan pekerjaan rutin dan penentuan pembagian tugas untuk hari atau minggu berikutnya. Perencanaan tindakan (action planning) adalah pengembangan dari langkah-langkah tindakan yang terinci dan pengaturan untuk membuat perubahan yang penting, implementasi kebijakan yang baru, atau menjalankan sebuah proyek. ${ }^{8}$

Aspek yang penting dari perencanaan adalah memutuskan bagaimana mengalokasikan sumber daya di antara berbagai kegiatan sesuai dengan kepentingan relatifnya. Termasuk di dalam perencanaan juga pengembangan prosedur untuk menghindari masalah-masalah atau bencana dan pengembangan prosedur untuk melakukan tanggapan secara cepat dan efektif terhadap masalah-masalah yang tidak dapat dihindari.

\section{Pengorganisasian Evaluasi Kinerja Guru}

Pengorganisasian adalah fungsi manajemen dan merupakan suatu proses yang dinamis. Menurut Manullang dalam Malayu Hasibuan, pengorganisasian merupakan suatu proses penetapan dan pembagian pekerjaan yang akan dilakukan, pembatasan tugas-tugas atau tanggung jawab serta wewenang dan penetapan hubungan-hubungan antara unsur-unsur organisasi, sehingga memungkinkan orang-orang dapat bekerja barsama-sama

\footnotetext{
${ }^{8}$ Ibid., hlm. 67.
} 


\section{8 | Harjali}

seefektif mungkin untuk pencapaian tujuan. ${ }^{9}$ Jika proses pengorganisasian evaluasi kinerja dilakukan dengan baik dan berdasarkan alamiah maka organisasi yang disususn akan baik, efektif, efisien, dan sesuai dengan kebutuhan lembaga dalam mencapai tujuannya.

Dalam pengorganisasian, agar semua anggota dapat melakukan tugas sesuai dengan kewajibannya, maka koordinasi antar anggota harus berjalan dengan lancar. Koordinasi sangat perlu dilakukan sesering mungkin sesuai dengan kebutuhan untuk menghindari perilaku anggota yang berjalan dengan kemauannya sendiri. Koordinasi bisa berbentuk pemantapan terhadap visi dan misi lembaga yang barangkali belum terlalu dipahami oleh segenap anggota. Koordinasi akan memegang peranan penting untuk menjaga kesolidan sebuah organisasi.

Sudewo dalam Sudirman, memaparkan beberapa faktor yang harus dilibatkan dalam koordinasi yaitu (1) pimpinan, dalam organisasi pendidikan, bagus atau tidaknya organisasi sedikit banyak akan tergantung kepada pimpinannya.Oleh sebab itu, koordinasi harus melibatkan pihak pimpinan agar diketahui kemana arah organisasi yang diinginkan pimpinan. (2) kualitas anggota,sebuah organisasi sangat membutuhkan sumber daya manusia yang berkualitas. Kapasitas anggota akan menjadi unsur penting dalam membangun citra organisasi.

Sistem,akan menjadikan sebuah organisasi lebih lama bertahan hidup. Agar suatu sistem dapat dilaksanakan secara maksimal,

9 Sudirman, Zakat dalam Pusaran Arus Modernitas (Malang: UIN Malang Press: 2007), Cet ke-1, hlm. 83. 


\section{9 | Harjali}

diperlukan kerjasama yang utuh antar komponen organisasi sehingga sistem yang dibuat sesuai dengan aspirasi anggota. ${ }^{10}$

\section{Pelaksanaan Evaluasi Kinerja Guru}

Pada hakekatnya pelaksaan program evaluasi kinerja merupakan fungsi administrasi yang dilaksanakan agar tugas, fungsi tanggung jawab dan wewenang yang telah diorganisasikan berjalan sesuai dengan kebijakan dan rencana yang telah ditetapkan dalam rangka mencapai tujuan secara efektif dan efisien. Pelaksanaan dalam sebuah manajemen adalah aktualisasi perencanaan yang dicanangkan oleh organisasi.

Jadi dalam pelaksanaan evaluasi kinerja menerangkan mengenai bagaimana proses evaluasi kinerja tersebut dilaksanakan. Dalam pelaksanaan program evaluasi kinerja terdapat beberapa komponen yang sangat diperlukan, diantaranya adalah motivasi, komunikasi, dan kepemimpinan. ${ }^{11}$

\section{Pengawasan Evaluasi Kinerja Guru}

Pengawasan program atau disebut juga dengan evaluasi program merupakan suatu rangkaian kegiatan yang dilakukan dengan sengaja untuk melihat tingkat keberhasilan program evaluasi kinerja. Melakukan evaluasi program kinerja adalah kegiatan yang dimaksudkan untuk mengetahui seberapa tinggi tingkat keberhasilan dari kegiatan yang direncanakan. Titik

\footnotetext{
${ }^{10}$ Ibid., hlm. 84-85.

${ }^{11}$ Ibid., hlm. 86.
} 


\section{0 | Harjali}

awal dari kegiatan evaluasi program adalah untuk melihat apakah tujuanprogram evaluasi kinerja sudah tercapai atau belum, ${ }^{12}$ sehingga dapat diketahui apa saja kendala dan solusi dalam melaksakan evaluasi kinerja guru di lembaga pendidikan tersebut.

Secara singkat dapat dikatakan bahwa tujuan pengawasan adalah preventif dan represif. Preventif mengacu pada pencegahan timbulnya penyimpangan pelaksanaan kerja organisasi dari perencanaan yang telah disusun sebelumnya. Represif dalam arti usaha mencapai ketaat-azasan dan kedisiplinan menjalankan setiap aktifitas agar memiliki kepastian hukum dan menetapkan perbaikan jika terdapat penyimpangan. Secara umum pengawasan program bertujuan untuk perbaikan program bagi program yang telah disusun. ${ }^{13}$

\section{Metode Penelitian}

Penelitian ini menggunakan pendekatan kualitatif yang berlangsung dalam latar yang wajar dengan menggunakan paradigma fenomenologis karena bertujuan memahami fenomena-fenomena yang terjadi dalam subyek penelitian. Pendekatan kualitatif menurut Kriek dan Miller dalam Moleong merupakan tradisi tertentu dalam ilmu pengetahuan sosial yang bergantung pada pengamatan manusia dalam kawasannya yang

12 Suharsimi Arikunto, Dasar-dasar Evaluasi Pendidikan, (Jakarta: Bumi Aksara, 2001), Cet.ke- 2, hlm. 290-291.

${ }^{13}$ Ibid., hlm. 80. 


\section{1 | Harjali}

berhubungan dengan orang-orang tersebut dalam bahasa dan peristilahannya. $^{14}$

Jenis penelitian ini adalah studi kasus. Dalam penelitian ini penulis akan menelaah secara komprehensi, mendetail, dan mendalam. Studi kasus merupakan salah satu jenis penelitian yang menekankan pada pendalaman kasus-kasus tertentu secara spesifik, sehingga data yang diperoleh akan komprehensif dan maksimal.Dalam penelitian ini kasus yang diangkat adalah kasus implementasi evaluasi kinerja guru di Madrasah Aliyah Al-Islam Joresan Mlarak Ponorogo.

Dalam penelitian kualitatif instrumen penelitian adalah peneliti sendiri. Instrumen penelitian tidak bersifat eksternal atau objektif, akan tetapi internal atau subjektif yaitu peneliti itu sendiri sebagai instrument kunci. Oleh karena itu, kehadiran peneliti secara langsung dalam lapangan penelitian, yakni MA. Al-Islam Joresan Mlarak merupakan keharusan dalam penelitian kualitatif.

Sumber data adalah kepala sekolah, dan perwakilan guru yang mengajar di lembaga tersebut. Kepala sekolah dan beberapa perwakilan guru. Dalam penelitian kualitatif jumlah sampel bukan merupakan kriteria utama, akan tetapi lebih ditekankan kepada sumber data yang dapat memberikan informasi yang sesuai dengan tujuan penelitian. Jenis data yang penulis kumpulkan berupa data tertulis, kata-kata dan tindakan,

14 Lexy Moleong, Metodologi Penelitian kualitatif (Bandung: Remaja Rosdakarya, 2002), Cet. ke-17, hlm. 4. 


\section{2 | Harjali}

format penilaian, foto atau gambar, statistik, serta data yang dapat mendukung penulis terhadap fokus penelitian. ${ }^{15}$

Dalam penelitian ini, metode yang dipakai dalam mengumpulkan data adalah wawancara dan dokumentasi. Data kemudian dioalah dan dianalisis. Salah satu sifat desain penelitian kualitatif adalah analisis data bersifat terbuka, yang berarti bahwa penelitian ini terbuka bagi perubahan, perbaikan dan penyempurnaan berdasarkan data baru yang masuk. ${ }^{16}$ Tahap ini merupakan salah satu tahap terpenting dalam penelitian. Analisa yang akan dilakukan dalam penelitian ini adalah analisa deskriptif kualitatif, yakni analisa yang mengedepankan penggambaran obyek penelitian secara mendetail, khususnya yang berkaitan dengan rumusan yang telah ditetapkan. Teori yang menjadi dasar pijakan dalam penelitian akan dikaitkan secara simultan dengan data lapangan. Dengan demikian, analisa ini akan menghasilkan sebuah kesimpulan hasil interpretasi ${ }^{17}$ yang dapat digunakan oleh para penggerak dunia pendidikan, khususnya dalam hal manajemen evaluasi kinerja guru.

Cara yang peneliti lakukan dalam triangulasi sumber tersebut adalah: 1) Membandingkan data hasil wawancara dengan observasi dan dokumentasi, untuk memperoleh data mengenai Evaluasi Kinerja Guru di MAAl-Islam Joresan

15 Soerjono Soekamto, Pengantar Penelitian Hukum (Jakarta: UIPress, 2006), Cet.ke-3, hlm. 51.

${ }^{16}$ S. Nasution, Penelitian Naturalistik Kualitatif (Bandung: Tarsito, 1996), hlm. 29.

${ }^{17}$ Masri Singarimbun dan Sofian Efendi, Metode Penelitian Survai (Jakarta: LP3ES, 1987), hlm. 254-257. 


\section{3 | Harjali}

Mlarak Ponorogo, peneliti mengumpulkan data dari beberapa informan antara lain kepala Sekolah dan beberapa guru yang dapat memberikan informasi secara representatif dan sesuai dengan kebutuhan penelitian. 2) membandingkan pendapat informan dengan informan lainnya. Dalam penelitian ini, data yang penulis peroleh dari kepala sekolah dan guru akan penulis bandingkan, apakah terdapat keselarasan informasi atau tidak. Triangulasi sumber ini dimaksudkan agar data yang diperoleh dalam penelitian ini lebih lengkap. Dengan demikian akan diketahui akurat atau tidaknya data yang peneliti peroleh.

\section{Hasil Penelitian Dan Pembahasan}

Dalam persepektif manajemen, agar kinerja guru dapat selalu ditingkatkan dan mencapai standar tertentu, maka dibutuhkan suatu manajemen kinerja. Begitu pula dengan program evaluasi kinerja guru di MA Al-Islam Joresan Mlarak Ponorogo, program tersebut juga mengacu pada prinsip manajemen yang meliputi empat komponen, yaitu (1) Perencanaan evaluasi kinerja guru , (2) Pengorganisasian evaluasi kinerja guru, (3) Pelaksanaanevaluasi kinerja guru, (4) Pengawasan evaluasi kinerja guru di MA Al-Islam Joresan Mlarak Ponorogo.

\section{Perencanaan Evaluasi Kinerja Guru di MAAl-Islam Joresan Mlarak Ponorogo}

Perencanaan evaluasi kinerja guru di MA Al-Islam Joresan MlarakPonorogo sudah direncanakan sejak awal 


\section{4 | Harjali}

berdirinlembaga yang tertulis di dalam Kesepakatan Kerja Bersama (KKB). Di dalam KKB pada pasal 9 butir 1 tentang promosi, sudah dijelaskan bahwa seorang guru atau karyawan dapat dinaikkan ke jenjang jabatan yang lebih tinggi berdasarkan kebijakan yayasan dan dengan memperhatikan hasil evaluasi prestasi kerja dan potensi yang dimiliki guru dan karyawan serta pertimbangan kebutuhan organisasi. ${ }^{18}$ Dengan demikian adanya evaluasi kinerja guru yang dilakukanMAAlIslam Joresan MlarakPonorogo telah disosialisasikan sejak perekrutan guru atau karyawan baru.

Program evaluasi kinerja guru yang dilakukan di MA AlIslam Joresan Mlarak Ponorogo ini bertujuan untuk mengevaluasi profesi teraplikasi, meningkatkan kinerja secara menyeluruh, dan pemetaan guru secara menyeluruh. Dengan evaluasi kinerja guru, diharapkan profesonalitas guru di MA AlIslam Joresan MlarakPonorogo semakin meningkat. Untuk mencapai tujuan tersebut selain dilakukan evaluasi kinerja guru, MA Al-Islam Joresan Mlarakjuga melakukan pembinaan secara berkala kepada para guru di MA Al-Islam Joresan Mlarak Ponorogo.

Format penilaian yang berisi instrumen penilaian yang digunakan pada saat evaluasi kinerja disebut dengan rapor guru. Format tersebut disusun oleh kepala sekolah dibantu oleh tim evaluator yaitu waka kurikulum, wakasarana dan prasarana, dan waka kesiswaan. Format yang dibuat tersebut diajukan kepada kepala sekolah, apabila ada kekurangan maka akan

\footnotetext{
${ }^{18}$ Dokumentasi, tanggal 02 September 2015.
} 


\section{5 | Harjali}

diberi masukan, dan apabila terdapat beberapa hal yang tidak perlu maka akan dikurangi. Saat ini kepala sekolah sedang menyusun format penilaian yang baru untuk evaluasi kinerja guru yang akan datang. Format penilaian yang baru tersebut direncanakan akan digunakan pada semester dua tahun ajaran 2014/2015. Kepala sekolah merencanakan melakukan pengamatan setiap bulan yang nantinya akan diakumulasikan pada hasil evaluasi kinerja selama satu tahun.

Dalam perencanaan juga akan disusun mengenai indiktor atau aspek apa saja yang akan dinilai dalam proses evaluasi kinerja guru di MA Al-Islam Joresan Mlarak Ponorogo. Aspek tersebut adalah aspek profesional, kompetensi, dan aspek bimbingan. Aspek profesional terdiri dari beberapa indikator yaitu: presensi, ketepatan datang dan pulang, izin terlambat, izin pulang awal, keaktifan dalam pembinaan, performance, antusiasm, pengendalian diri, kerapian dan kebersihan kelas, dan ketepatan pengumpulan tugas. Aspek yang kedua adalah aspek kompetensi yang terdiri dari beberapa indikator yaitu: pengelolaan kelas, penguasaan materi, program semester, kemampuan siswa, relefansi nilai rapor serta classroom climate atau suasana kelas dalam proses belajar mengajar. Aspek yang ketiga adalah aspek bimbingan, aspek bimbingan ini terdiri dari beberapa indikator yaitu: bimbingan aktivitas belajar, bimbingan aktivitas shalat, pelaksanaan buku penghubung, sikap dan perilaku anak baik terhadap guru maupun kepada teman, atensi terhadap buku tugas dan catatan, perlengkapan siswa, presensi siswa, serta ketepatan datang dan pulang siswa. 


\section{6 | Harjali}

Selain itu kepala sekolah juga menetapkan prosedur dalam pelaksanaan evaluasi kinerja guru di MA Al-Islam Joresan Mlarak Ponorogo.

Berdasarkan pedoman Departemen Pendidikan Nasional tahun 2005 tentang instrumen penilaian kinerja sekolah khususnya dalam komponen kinerja guru, meliputi dua bidang yaitu (1) akademik dan (2) non akademik. Adapun bidang akademik meliputi tiga unsur yaitu (a) pengembangan pribadi yang memiliki tiga aspek yaitu aspek aplikasi pengajaran, aspek kegiatan ekstra kurikuler dan aspek kualitas pribadi guru, (b) unsur pembelajaran, memiliki tiga aspek yaitu aspek perencanaan, aspek pelaksanaan, dan aspek evaluasi, (c) unsur sumber belajar memiliki dua aspek yaitu aspek ketersediaan bahan ajar dan aspek pemanfaatan sumber belajar. Sedangkan bidang non akademik memiliki satu unsur yaitu unsur kepribadian yang memiliki tujuh aspek yatu: kediplinan, etos kerja, kerjasama, inisiatif, tanggung jawab, kejujuran dan prestasi kerja.

Instrument penilaian kinerja yang diberlakukan di MA AlIslam Joresan MlarakPonorogo tidak jauh berbeda dengan instrument penilaian yang ditetapkan oleh departemen pendidikan nasional. Hanya saja tidak semua indikator yang ditetapkan oleh Departemen Pendidikan Nasional digunakan secara keseluruhan, akan tetapi diambil beberapa saja yang bisa mewakili dari aspek penilaian kinerja tersebut. Dari istrumen yang dibuat merupakan pengembangan dari kompetensi yang harus dimiliki oleh guru yang disebutkan dalam peraturan 


\section{7 | Harjali}

pemerintah tentang diwajibkannya seorang guru untuk memiliki empat kompetensi pokok yaitu kompetensi pedagogik, kompetensi profesional, kompetensi kepribadian, dan kompetensi sosial.

. Kompetensi pedagogik meliputi pemahaman terhadap peserta didik, perancangan dan pelaksanaan pembelajaran, evaluasi hasil belajar, dan pengembangan peserta didik untuk mengaktualisasikan berbagai potensi yang dimilikinya. Kompetensi profesional merupakan penguasaan materi pembelajaran secara luas dan mendalam, yang mencakup penguasaan materi kurikulum mata pelajaran di sekolah dan substansi keilmuan yang menaungi materinya, serta penguasaan terhadap struktur dan metodologi keilmuannya. Kompetensi sosial merupakan kemampuan guru untuk berkomunikasi dan bergaul secara efektif dengan peserta didik, sesama pendidik, tenaga kependidikan, orang tua/wali peserta didik, dan masyarakat.Kompetensi kepribadian merupakan kemampuan yang terdiri dari beberapa sub kompetensi personal yang mencerminkan kepribadian yang mantap, stabil, dewasa, arif, dan berwibawa, menjadi teladan bagi peserta didik, dan berakhlak mulia

\section{Pengorganisasian Evaluasi Kinerja Guru di MAAl-Islam} Joresan Mlarak Ponorogo

Manullang dalam Hasibuan menyatakan bahwa pengorganisasian merupakan suatu proses penetapan dan pembagian pekerjaan yang akan dilakukan, pembatasan tugas- 


\section{8 | Harjali}

tugas atau tanggung jawab serta wewenang dan penetapan hubungan-hubungan antara unsur-unsur organisasi, sehingga memungkinkan orang-orang dapat bekerja bersama-sama seefektif mungkin untuk pencapaian tujuan. ${ }^{19}$

Pengorganisasian dalam program evaluasi kinerja guru di MAAl-Islam Joresan Mlarak sudah tertata dengan bagus. Dalam program evaluasi kinerja yang sudah dilakukan, kepala sekolah berperan sebagai evaluator utama, kepala sekolah dibantu oleh tim yang terdiri dari waka kurikulum, waka kesiswaan dan waka sarana prasarana. Masing-masing waka bertugas untuk melakukan evaluasi kapada semua guru secara bergantian dengan masing-masing aspek penilaian yang berbeda.

Kepala sekolah membuat format penilaian kinerja, mensosialisasikan dan melaksanakan evaluasi kinerja kepada seluruh guru MA Al-Islam Joresan Mlarak. Kepala sekolah dibantu oleh waka kurikulum untuk menilai aspek professional kepada seluruh guru yang mengajar di MA Al-Islam Joresan Mlarak Ponorogo. Aspek professional tersebut terdiri dari beberapa indikator yaitu: presensi, ketepatan datang dan pulang, izin terlambat, izin pulang awal, keaktifan dalam pembinaan, performance (rapi dan bersih), antusiasme (ekspresi dan suara), pengendalian diri, kerapian dan kebersihan kelas, dan ketepatan pengumpulan tugas. Waka kesiswaan membantu kepala sekolah dalam melakukan penilaian pada aspek kompetensi yang terdiri dari beberapa indikator yaitu: pengelolaan kelas, penguasaan

19 Malayu S.P. Hasibuan, Manajemen Dasar, Pengertian dan Masalah (Jakarta: PT. Bumi Aksara: 2005), Cet. Ke-5, hlm. 118-119. 


\section{9 | Harjali}

materi, program semester, kemampuan siswa, relefansi nilai rapor serta classroom climate atau suasana kelas dalam proses belajar mengajar.

Waka sarana prasarana membantu kepala sekolah melakukan penilaian pada aspek yang ketiga yaitu aspek bimbingan. Aspek bimbingan ini terdiri dari beberapa indikator yaitu: bimbingan aktifitas belajar, bimbingan aktifitas shalat, pelaksanaan buku penghubung, sikap dan perilaku anak baik terhadap guru maupunkepada teman, atensi terhadap buku tugas dan catatan, perlengkapan siswa, presensi siswa, ketepatan datang dan pulang siswa, membuang sampah pada tempatnya.

Struktur organisasi yang digunakan dalam program evaluasi kinerja guru di MA Al-Islam Joresan Mlarak Ponorogo adalah struktur organisasi lini yang diciptakan oleh Hanry Fayol. Dimana pendelegasian wewenang dilakukan secara vertikal melalui garis terpendek dari seorang atasan kepada bawahannya. ${ }^{20}$ Koordinasi antar anggota dalam program evaluasi kinerja di MAAl-Islam Joresan MlarakPonorogo sudah bagus. Masing-masing koordinator memiliki tugas dan tanggung jawab yang berbeda-beda sehingga tidak terjadi tumpang tindih dalam melaksanakan tugas. Hal tersebut sesuai dengan yang dikatakan Sudirman bahwa yang dimaksud dengan pengorganisasian adalah cara yang ditempuh oleh sebuah lembaga untuk mengatur kinerja lembaga termasuk para anggotanya. Pengorganisasian tidak lepas dari koordinasi, yang

${ }^{20}$ Ibid, hlm. 125 
sering didefinisikan sebagai upaya penyatuan sikap dan langkah dalam sebuah organisasi untuk mencapai tujuan. ${ }^{21}$

\section{Pelaksanaan Evaluasi Kinerja Guru di MA Al-Islam Joresan Mlarak Ponorogo}

Pelaksanaan dalam sebuah manajemen adalah aktualisasi perencanaan yang dicanangkan oleh organisasi. Jadi dalam pelaksanaan evaluasi kinerja menerangkan mengenai bagaimana proses evaluasi kinerja tersebut dilaksanakan. Dalam pelaksanaan program evaluasi kinerja terdapat beberapa komponen yang sangat diperlukan, diantaranya adalah motivasi, komunikasi, dan kepemimpinan.

Pelaksanaan program evaluasi kinerja dilakukan setiap satu tahun sekali pada akhir tahun ajaran yakni antara bulan MeiJuni. Evaluasi dilakukan secara serentak kepada seluruh jajaran baik gurubahasa Inggris maupun guru mata pelajaran yang lain. Sosialisasi dilakukan pada satu bulan sebelum format penilaian dibagikan kepada seluruh jajaran. Dua minggu kemudian, format dibagikan untuk diisi oleh masing-masing guru sesuai dengan penilaian mereka sendiri. Dengan demikian metode yang digunakan oleh MA Al-Islam Joresan MlarakPonorogo adalah metode penilaian pada diri sendiri dan selanjutnya di diskusikan dengan tim evaluator. Metode penilaian tersebut bertujuan untuk mengembangkan diri sendiri untuk kemajuan di masa yang akan datang.

Dalam pelaksanaan program evaluasi kinerja yang dilakukan di MA Al-Islam Joresan Mlarak Ponorogo para guru

${ }^{21}$ Sudirman, Zakat dalam Pusaran Arus Modernitas ..... hlm. 83 . 
memiliki motivasi yang tinggi ketika mereka hendak dievaluasi. Mereka mempersiapkan diri menjelang evaluasi dilaksanakan. Mereka juga merasa diperhatikan oleh lembaga dan selalu bersemangat dalam bertugas. Hal tersebut menunjukkan bahwa para pengajar di MAAl-Islam Joresan MlarakPonorogo memiliki motivasi yang tinggi. Hal ini bisa dikarenakan mereka mengetahui timbal balik yang akan mereka dapatkan, yaitu kenaikan gaji atau kenaikan jenjang karir. Sesuai dengan teori pengharapan yang dikemukakan oleh Victor Vroom bahwa karyawan dimotivasi untuk menjalakan tingkat upaya yang tinggi bila ia meyakini upaya tersebut akan menghantarkan ke sesuatu penilaian kinerja yang baik; penilaian kinerja yang baik akan mendorong ganjaran organisasional seperti bonus, kenaikan gaji, atau promosi; dan ganjaran itu akan memuaskan tujuan pribadi karyawan tersebut. ${ }^{22}$

Timbal balik dari evaluasi kinerja guru yang sudah dilakukan di MAAl-Islam Joresan MlarakPonorogo selama ini adalah memberikan imbalan berupa piagam penghargaan dan biasiswa studi. Pelaksanaan evaluasi kinerja guru di MA AlIslam Joresan MlarakPonorogo tidak akan dapat berjalan dengan baik apabila tidak ada komunikasi yang baik antara tim evaluator dengan yang dievaluasi.

\section{Pengawasan Evaluasi Kinerja Guru di MA Al-Islam Joresan Mlarak Ponorogo}

22 Victor Vroom dalam tesis Wakidi, Pembinaan Profesionalitas Guru Pada Lembaga Pendidikan Islam, (UIIS Malang, 2002) hlm. 61-62. 
Pengawasan program atau disebut juga dengan evaluasi program merupakan suatu rangkaian kegiatan yang dilakukan dengan sengaja untuk melihat tingkat keberhasilan program evaluasi kinerja. Melakukan evaluasi program kinerja adalah kegiatan yang dimaksudkan untuk mengetahui seberapa tinggi tingkat keberhasilan dari kegiatan yang direncanakan. Titik awal dari kegiatan evaluasi program adalah untuk melihat apakah tujuan program evaluasi kinerja sudah tercapai atau belum. $^{23}$

Pengawasan program merupakan proses aktivitas yang meliputi kegiatan pengecekan, penilaian, pengoreksian yang berdasarkan pada rencana, perintah dan prinsip suatu organisasi dengan tujuan mengendalikan dan mengembangkan kegiatan organisasi. Evaluasi program memiliki beberapa tujuan, yaitu agar pelaksanaan tugas sesuai dengan ketentuan, prosedur serta perintah yang telah ditetapkan; agar hasil yang dicapai sesuai dengan tujuan yang telah ditetapkan; agar sarana yang ada dapat didayagunakan secara efektif dan efisien, dan agar diketahui kelemahan dan kesulitan organisasi, kemudian dicari jalan keluarnya. Secara singkat dapat dikatakan bahwa tujuan pengawasan program adalah preventif dan represif. Preventif mengacu pada pencegahan timbulnya penyimpangan pelaksanaan kerja organisasi dari perencanaan yang telah disusun sebelumnya. Represif dalam arti usaha mencapai ketaat-azasan dan kedisiplinan menjalankan setiap aktifitas agar

${ }^{23}$ Suharsimi Arikunto, Dasar-dasar Evaluasi Pendidikan, (Jakarta: Bumi Aksara, 2001), Cet.ke- 2, hlm. 290-291. 
memiliki kepastian hukum dan menetapkan perbaikan jika terdapat penyimpangan.

Pengawasan program evaluasi kinerja guru di MAAl-Islam Joresan MlarakPonorogo dilakukan satu tahun sekali, dalam pengawasan tersebut dilakukan peninjauan ulang pada format penilaian yang dipakai apakah masih layak atau tidak, tujuan evaluasi sudah tercapai apa belum, mencari hal-hal yang menjadi kendala dalam program evaluasi yang menentukan jalan keluarnya dengan cara bermusyawarah dengan tim evaluator. Setelah dilakukan pengawasan pada program evaluasi kinerja guru di MA Al-Islam Joresan MlarakPonorogo ternyata ditemukan kendala yang menghambat terlaksananya evaluasi kinerja guru di MA Al-Islam Joresan Mlarak Ponorogo. Kendala tersebut adalah adanya perbedaan para meter terhadap format penilaian kinerja yang digunakan antara tim evaluator dengan yang dievaluasi. Akan tetapi hal tersebut dapat diselesaikan melalui musyawarah untuk menyamakan persepsi, sehingga menghasilkan keputusan yang terbaik.

Berdasarkan pengamatan peneliti, kendala tersebut terjadi karena tidak dilibatkannya guru dalam penyusunan instrumen atau format penilaian yang digunakan. Hal tersebut bertentangan dengan teori pengorganisasian yang mengharuskan adanya koordinasi yang baik antar anggota dalam sebuah organisasi. Artinya apabila dalam lembaga tersebut merencanakan suatu program, maka tujuan, prosedur, dan format yang akan digunakan harus disosialisasikan. 


\section{E. Penutup}

\section{Perencanaan Evaluasi Kinerja Guru di MA. Al-Islam Joresan Mlarak Ponororgo}

Dari penelitian yang telah penulis lakukan di MA Al-Islam Joresan MlarakPonorogo dapat disimpulkan bahwa program evalusi kinerja guru yang dilaksanakan berpegang pada prinsip manajemen yang dicetuskan oleh Terry, yang meliputi empat komponen, yaitu perencanaan, pengorganisasian, pelaksanaan dan pengawasan program evaluasi kinerja guru.

Dalam perencanaan, telah disusun tujuan, format dan prosedur pelaksanaan program evaluasi kinerja guru yang dilakukan oleh MA Al-Islam Joresan Mlarak Ponorogo. Format penilaian kinerja di MAAl-Islam Joresan Mlarakdibuat dan disusun oleh kepala sekolah beserta tim evaluator. Prodesur evaluasi kinerja yang dilakukan oleh MAAl-Islam Joresan MlarakPonorogo adalah menggunakan metode penilaian pada diri sendiri, kemudian didiskusikan dengan tim evaluator. Hasil akhir dari evaluasi kinerja tersebut ditentukan oleh tim evaluator dan kepala sekolah,

\section{Pengorganisasian Evaluasi Kinerja Guru di MA Al-Islam Joresan Mlarak Ponorogo}

Struktur organisasi dalam program evaluasi kinerja guru di MA Al-Islam Joresan MlarakPonorogo merupakan bentuk organisasi lini yang dicetuskan oleh Henry Fayol, di mana struktur tersebut terdiri dari Kepala sekolah, waka kurukulum, waka kesiswaaan, dan waka sarana dan prasarana. Masingmasing koordinator memiliki kewenangan untuk mengevaluasi 
di bawah pengawasan kaur bidang kurikulum. Dengan demikian sudah ada pembagian tugas bagi masing-masing kaur untuk menghindari tumpang tindih tanggung jawab.

\section{Pelaksanaan Evaluasi Kinerja Guru di MA Al-Islam Joresan Mlarak Ponorogo}

Evaluasi kinerja guru dilaksanakan satu tahun sekali pada akhir tahun pelajaran, pada setiap harinya tim evaluator melakukan pengamatan dan akan mengakumulasikan dengan hasil evaluasi pada akhir tahun. Pelaksanaan evaluasi kinerja guru di MA Al-Islam Joresan MlarakPonorogo dilakukan secara serentak kepada seluruh karyawan baik guru maupun pegawai. Agar pelaksanaan evaluasi kinerja guru di MA Al-Islam Joresan MlarakPonorogo dapat berjalan dengan baik, kepala sekolah mensosialisasikan kepada seluruh guru dan karyawan mengenai waktu, metode, serta prosedur yang digunakan dalam proses evaluasi.

\section{Pengawasan Evaluasi Kinerja Guru diMAAl-Islam Joresan Mlarak Ponorogo}

Pengawasan program evaluasi kinerja guru di MA Al-Islam Joresan MlarakPonorogo dilakukan dalam waktu satu tahun sekali. Dengan dilaksanakannya pengawasan akan membantu tim evaluator untuk bisa mengetahui apa saja yang menjadi kendala dalam melaksanakan proses evaluasi kinerja serta mencari solusinya, dan dengan pengawasan juga kita bisa mengetahui kekurangan dan kelebihan format, metode dan prosedur evaluasi kinerja, sehingga dapat menetukan langkah yang lebih baik untuk masa yang akan datang. 


\section{DAFTAR PUSTAKA}

Arikunto, Suharsimi Dasar-dasar Evaluasi Pendidikan, (Jakarta: Bumi Aksara, 2001).

Depdiknas, Instrumen Penilaian Kinerja Departemen Pendidikan Nasional, (Jakarta: Dirjen Dikdasmen, 2005).

Gary Yukl,.alih bahasa: Jusuf Udaya, Kepemimpinan Dalam Organisasi, (Jakarta: Prenhalindo,1994).

Mulyasa, E. Kurikulum Berbasis Kompetensi, (Bandung: PT. Remaja Rosdakarya, 2003).

Hasibuan, Malayu, Manajemen, Dasar, Pengertian dan Masalah, (Jakarta: Sinar Grafika Offset, 2005).

Jefkins, Frank, Public Relations, (Jakarta: PT Rajawali Press, 1992).

Mitchell, T. R. People In Organizational Understanding The Behavior, tejemah Sedarmayanti, (Kogakhusa: McGraw-Hill, 1978).

Moleong, Lexy, Metodologi Penelitian kualitatif, (Bandung: Remaja Rosdakarya, 2002).

Mulyasa, Kurikulum Tingkat Satuan Pendidikan, (Bandung: PT. Rosdakarya: 2006).

Mulyasa, Manajemen Berbasis Sekolah Konsep, Strategi, dan Implementasi, (Bandung: PT. Remaja Rosdakarya, 2003).

Pidarta, Made, Manajemen Pendidikan Indonesia, (Jakarta: Rineka Cipta, 2004).

Romlah, Futiati, Profesionalisme Guru dan Pengaruhnya Terhadap Hasil Belajar Siswa, (Jurnal Kependidikan dan Kemasyarakatan: STAIN Ponorogo, Vol. 3, 2005). 
Smith, Mary Lee \& Glass Gene V. Research and Evaluation in Educationa and the Social Science, (Englewood Cliffs New Jersey: Prentice Hall, Inc, 1987).

Singarimbun, Masri dan Sofian Efendi, Metode Penelitian Survai, (Jakarta: LP3ES, 1987).

Shertzer, Bruce \& Shelley Stone, Fundamental of Guidance, (Fouth Edition, USA: Purdue Univercity, 1981).

Supriyanto, John, Penilaian Kinerja dan Pengembangan Karyawan, (Yogyakarta: BPFE, 2001).

S, Nasution, Penelitian Naturalistik Kualitatif, (Bandung: Tarsito, 1996).

Sahertian, Konsep Dasar dan Teknik Supervisi Pendidikan dalam Rangka Pengembangan SDM, (Jakarta: Rineka Cipta, 2000).

Soekamto, Soerjono, Pengantar Penelitian Hukum, (Jakarta: UI-Press, 2006).

Sudirman, Zakat Dalam Pusaran Arus Modernitas, (Malang: UIN Malang Press, 2007).

Usman, M. Uzer, Menjadi Guru Profesional, (Bandung: PT. Remaja Rosdakarya: 2003).

Undang-undang Republik Indonesia Nomor 20 Tentang Sistem Pendidikan Nasional, (Jakarta: Kloang Klende Putra, 2003).

Wexley dan Yukl, Perilaku Organisasi dan Psikologi Personalia, (Jakarta: PT. Bina Aksara, 1992).

Wakidi, Pembinaan Profesionalitas Guru Pada Lembaga Pendidikan Islam, (Tesis Program Pascasarjana UIN Malang: 2004). 